\title{
A survey of ciliates at the long-term sampling station "Helgoland Roads", North Sea
}

\author{
Jinpeng Yang • Martin Günther Joachim Löder • \\ Karen Helen Wiltshire
}

Received: 7 December 2013/Revised: 15 March 2014/ Accepted: 21 March 2014/Published online: 11 April 2014

(C) Springer-Verlag Berlin Heidelberg and AWI 2014

\begin{abstract}
This study presents a new checklist of ciliates at the long-term sampling station Helgoland Roads. The work is based on a microzooplankton monitoring programme from January 2007 to June 2009 and a ciliate monitoring programme from June 2010 to May 2012. The checklist includes 89 ciliate taxa from 46 different genera. The total abundance of the ciliate community at Helgoland Roads ranged between 0.14 and $67.7 \times 10^{3}$ cells $\mathrm{L}^{-1}$ with a distinct peak in June. The total carbon biomass ranged between 0.2 and $234.6 \mu \mathrm{g} \mathrm{C} \mathrm{L}^{-1}$. The ciliate community showed a clear temporal succession pattern during the monitoring periods. The present study is not only the first detailed and updated list of ciliates at Helgoland Roads, but also provides information on seasonality, i.e. the temporal variation of species composition, abundance and carbon biomass as well as information on the biogeographic distribution of dominant ciliates in comparison with other relevant studies.
\end{abstract}

Keywords Plankton · North Sea · Seasonality ·

Biogeographic distribution · Helgoland Reede

\section{Introduction}

It is recognized that microzooplankton plays an important role in the microbial food web: on one hand as dominant

Communicated by H.-D. Franke.

J. Yang $(\bowtie) \cdot$ M. G. J. Löder · K. H. Wiltshire Biologische Anstalt Helgoland, Alfred Wegener Institut, Helmholtz Zentrum für Polar und Meeresforschung, Post Box 180, 27483 Helgoland, Germany

e-mail: jinpeng.yang@awi.de grazers of phytoplankton and on the other hand as an important link from the microbial loop to higher trophic levels (Azam et al. 1983; Sherr and Sherr 1987; Vargas et al. 2007, 2008; Löder et al. 2012). Ciliates make up a substantial proportion in terms of numbers as well as biomass and thus play a crucial role in microzooplankton communities (Finlay et al. 1979, 1988; Pratt and Cairns 1985; Edwards and Burkill 1995). Ciliates are commonly referred to as a taxonomic group with multiple ecological functions in the marine food web (Lynn 2008). They are primary grazers on pico- and nanoplankton within the size range of $0.2-20 \mu \mathrm{m}$, and meanwhile, they also serve as important food source for metazoans, such as copepods (Gifford 1991; Pierce and Turner 1992; Legendre and Rassouldezgan 1995; Xu et al. 2008; Löder et al. 2011). Some ciliates that harbour algal endosymbionts or plastids from ingested algal prey are mixotrophic and function as primary producers (Laval-Peuto et al. 1986; Stoecker et al. 1987). Some ciliates live as epibionts, and some parasitic ciliates are pathogenic to aquatic organisms, such as sea urchin and fish (Song et al. 2003). Ciliates also play a significant role in regulating bacterial populations (Song et al. 2009) and regenerating nutrients (Dolan 1997). They are commonly used as bioindicators on water quality since they can be sensitive to marine pollution due to their short generation time and delicate membranes (Caspers and Karbe 1967; Sládeček 1973; Song et al. 2009; Xu et al. 2011).

Marine research has a long tradition at Helgoland resulting in a unique data set of over 50 years long of comprehensive physical, chemical and biological data of the North Sea with a work-daily resolution (Franke et al. 2004; Greve et al. 2004; Wiltshire and Dürselen 2004; Wiltshire and Manly 2004). Although ciliates have received much attention over the last decades, no ciliate 
taxa had been recorded in the routine programme at Helgoland Roads before 1999. By 2007, some ciliates (Myrinecta rubra, Laboea strobila and Mesodinium pulex) were recorded routinely (www.pangaea.de). As a part of the assessment of the necessity for monitoring microzooplankton at Helgoland Roads, Löder et al. (2012) investigated the microzooplankton from January 2007 to June 2009, in which 62 ciliate taxa were recorded. Following upon this monitoring programme, a 2-year ciliate monitoring programme was established at Helgoland Roads in order to investigate the species composition and seasonality of the ciliate community in more detail and with higher frequency to gain more ecological information on this important functional group. During this period, the former checklist was supplemented with 27 additional ciliate taxa.

This study was aimed at providing the first detailed ciliate checklist at Helgoland Roads. This is crucial not only to obtain an idea of the ciliate diversity which was previously missing in the Helgoland Roads time series, but also to provide a basic reference for future surveys on microzooplankton communities in the North Sea where the ciliated protozoa have not been well studied and the existing documentations are out of date. In addition, the temporal distributions of dominant ciliate taxa are provided in this study to provide a good basis for further taxonomical and ecological studies in this marine region. The seasonal variation of the ciliate community in terms of species composition, abundance and carbon biomass is discussed and compared with relevant studies from other marine regions as well to enlighten the worldwide distributional patterns of dominant ciliate taxa recorded at Helgoland Roads.

\section{Materials and methods}

Helgoland Roads is located in the German Bight and is subject to both coastal influences and marine influences from the open North Sea (Wiltshire et al. 2010). The annual average temperature and salinity are $10.4{ }^{\circ} \mathrm{C}\left(\max 18.5^{\circ} \mathrm{C}\right.$, $\left.\min 2.0^{\circ} \mathrm{C}\right)$ and $32.0(\max 34.3$, $\min 28.4)$, respectively (www.pangaea.de). Surface water samples were taken at $7: 30$ in the morning at Helgoland Roads $\left(54^{\circ} 11.30^{\prime} \mathrm{N}\right.$; $7^{\circ} 54.00^{\prime} \mathrm{E}$ ) once a week from January 2007 until June 2009 (first monitoring period, Löder et al. 2012) and twice a week from June 2010 until May 2012 (second monitoring period). About $250 \mathrm{ml}$ of water sample was fixed with acid Lugol's solution (final concentration $2 \%$ ) immediately and stored in cold and dark conditions. Despite some drawbacks (e.g. obstruction on subsequent silver impregnation), acid Lugol's solution was used over other methods to ensure comparability over many years because all Helgoland Roads samples are fixed in it and have been so far nearly 80 years. Moreover, acid Lugol's solution causes much less cell losses than other fixatives (Stoecker et al. 1994).

Triplicate $50 \mathrm{~mL}$ subsamples (the second monitoring period) were settled using Utermöhl chambers (Utermöhl 1958) for at least $24 \mathrm{~h}$ to enhance the opportunity of recording rare species and to reduce the counting biases. The whole chamber was counted at 200-fold magnification under an inverted microscope (Zeiss Axiovert 135). Of each taxon recorded, images were taken and used for subsequent biovolume estimations as well as the documentation and assignment of rare species. The biovolume of each taxon was calculated according to the geometric models described by Hillebrand et al. (1999) after the measurement of the linear dimension of each taxon with the open source software "ImageJ". The average biovolume (at least 20 individuals for normal taxa and all individuals for rare taxa) was converted into carbon using the conversion factor $\left(0.19 \mathrm{pg} \mathrm{C} \mu \mathrm{m}^{-3}\right)$ given by Putt and Stoecker (1989) according to the Lugol's concentration used in this study. Carbon concentrations $\left(\mu \mathrm{g} \mathrm{C} \mathrm{L}^{-1}\right)$ in this study are referred to as biomass or carbon biomass. All samples were processed within 6 months. Additionally, concentrated samples from 20 to $80 \mu \mathrm{m}$ mesh size plankton nets were collected twice a week and examined under a light microscope in the laboratory for live observations of ciliates in order to obtain more morphological features for the identification.

All ciliate taxa observed and identified were listed. Due to difficulties that can occur with the identification of ciliates after fixation with acid Lugol's solution, some ciliates were only identified to genus level or put into different size groups or morphotypes (e.g. for some taxa in the complex genus Strombidium and scuticociliates). Most of the ciliate taxa in this study were identified mainly according to Montagnes (2003) for typical planktonic ciliates and Carey (1992) and Song et al. (2009) for periphytic and benthic ciliates. The identification of tintinnids was based on Kofoid and Campbell $(1929,1939)$. Local documentations for the German North Sea on ciliate fauna were also referred to, such as Hartwig (1973), Küsters (1974) and Maeda and Carey (1985). In this study, we applied the taxonomic systematics of Lynn (2008). Mixotrophy of the ciliates was not observed in the laboratory and thus is not actively differentiated to in this study. However, all ciliates except Mesodinium rubrum and Mesodinium major were considered heterotrophic. Johansson et al. (2004) have shown that all mixotrophic ciliates have phagotrophic capabilities. M. rubrum was recorded as mixotrophic, because recent studies have shown that it has phagotrophic capabilities (Park et al. 2007). M. major was recorded as phototrophic according to recent study by Garcia-Cuetos et al. (2012). 


\section{Results and discussion}

Taxonomic composition and temporal variation

The taxonomic checklist of the ciliate community at Helgoland Roads is presented in Table 1. During the two monitoring periods, 89 ciliate taxa, representing 46 different genera, were identified. In terms of diversity, the order Strombidiida was the most diverse group, accounting for $26 \%$ of the total taxa number, followed by Tintinnida and Choreotrichida, accounting for 16 and $12 \%$ respectively of the total taxa numbers. Throughout the whole monitoring period, the abundance exhibited an obvious temporal variation with generally high values in spring and summer, low values in autumn and winter and a distinct peak in June (maximum abundance $6.77 \times 10^{4}$ cells $\mathrm{L}^{-1}$, Fig. 1). This was mainly due to the bloom of two photosynthesis-performing ciliates M. rubrum and M. major (Fig. 2c, d) which were responsible for $83 \%$ of the peak in terms of cell numbers. The temporal variation of carbon biomass showed a similar pattern to that of abundance with a distinct peak in June (maximum value $234.58 \mu \mathrm{g} \mathrm{C} \mathrm{L}^{-1}$, Fig. 1).

In terms of carbon biomass, the order Strombidiida played the most important role during the monitoring, accounting for 51 and $42 \%$ of the carbon biomass respectively in the first and second monitoring period. $M$. rubrum and M. major became more dominant in the second monitoring and together were responsible for nearly $40 \%$ of carbon biomass ( $23 \%$ in the first monitoring), followed by Choreotrichida (7 and $10 \%$ respectively in the first and second monitoring) and Haptorida (6 and $2 \%$ respectively in the first and second monitoring). Tintinnida and Prorodontida played a smaller role (2-4\%). Other ciliate groups were of negligible importance from a biomass perspective, accounting for less than $1 \%$ of the carbon biomass for both monitoring periods.

Although the ciliate community was slightly variable every year with respect to species composition, abundance and carbon biomass, it exhibited a clear temporal succession pattern during the monitoring. Strombidiida normally dominated the ciliate community from March to May when ciliate abundance rapidly increased due to their quick response to enhanced food availability (Löder et al. 2012). $M$. rubrum and $M$. major became dominant since late spring and were the major contributors to the peak in June. After this distinct peak, they gradually decreased and continued to dominate the ciliate community together with aloricate oligotrichs and choreotrichs during the summer months when the ciliate community demonstrated a higher diversity (number of observed taxa: 70 in summer, 60 in spring, 64 in autumn and 44 in winter) as most of the rare ciliate taxa occurred during this time period. In autumn, Tiarina fusus and some tintinnids were present in the water column and contributed to the ciliate community. In winter, the ciliate community showed very low values in terms of both taxa number and abundance as well as carbon biomass.

Because of the importance of the Helgoland Time series in the international context (see Wiltshire et al. 2010, www.pangaea.de and ICES data banks) and the lack of information on microzooplankton at Helgoland and indeed in general when compared with other planktonic groups, detailed information on different ciliate groups is provided here below.

\section{Typically planktonic ciliate groups}

Aloricate oligotrichs and choreotrichs have been extensively studied over the recent decades in many different marine ecosystems, and they are broadly distributed all over the world (Lynn and Montagnes 1991; Pierce and Turner 1992; Garrison et al. 2005). They play an important role in microbial food webs (Gifford 1991; Pierce and Turner 1992; Liu et al. 2005) and dominate the marine microzooplankton communities episodically (Agatha 2011). Aloricate oligotrichs and choreotrichs represent the most important groups at Helgoland Roads. Their abundance increased intensively from March onwards due to their quick response to enhanced food availability and remained at a high level until late summer. They dominated the microzooplankton community together with M. rubrum and $M$. major during the spring bloom when heterotrophic dinoflagellates were still present in low numbers (Löder et al. 2012). Among them, the order Strombidiida was more diverse (23 taxa vs. 11 taxa) and abundant than the order Choreotrichida. Within the order Strombidiida, mediumsized species ranging between 30 and $60 \mu \mathrm{m}$ $\left(<50,000 \mu \mathrm{m}^{3}\right.$ cell volume) were normally quite abundant and comprised a main part of the total carbon biomass, e.g. Strombidium cf. acutum, S. cf. emergens (Fig. 2b), S. cf. epidemum, $S$. cf. stylifer, $S$. cf. sulcatum, $S$. cf. tressum and Tontonia gracillima (Fig. 2a). Large-sized species over $60 \mu \mathrm{m}\left(>50,000 \mu \mathrm{m}^{3}\right.$ cell volume $)$ contributed considerably to the carbon biomass, though most of them were less abundant than medium-sized species with the exception of L. strobila (Fig. 21) and Strombidium capitatum.

Within the order Choreotrichida, Lohmanniella oviformis (Fig. 2j) normally occurred in spring and summer with maxima of around $2.0 \times 10^{3}$ cells $\mathrm{L}^{-1}$. Strobilidium sp. 1 $(15 \mu \mathrm{m})$, whose maximum abundance was more than $1.0 \times 10^{4}$ cells $\mathrm{L}^{-1}$, normally occurred from late spring to autumn and was very abundant in summer. Other species in the order Choreotrichida were not so abundant over the year with an abundance ranging between 10 and 500 cells $\mathrm{L}^{-1}$, such as Pelagostrobilidium cf. neptunii (Fig. 2e) and Strombidinopsis sp. (Fig. 2h). 
Table 1 Revised ciliate checklist: seasonality as well as maximum abundance, the mean biovolume and mean carbon content of each taxon according to the results of both monitoring programmes and occurrence frequency of each taxon according to the results of the second monitoring

\begin{tabular}{|c|c|c|c|c|c|c|}
\hline Ciliates & $\begin{array}{l}\text { Observed } \\
\text { seasonality }\end{array}$ & $\begin{array}{l}\text { Occurrence } \\
\text { frequency }(\%)^{\mathrm{a}}\end{array}$ & $\begin{array}{l}\text { Maximum } \\
\left(\text { cells L L }^{-1}\right)\end{array}$ & $\begin{array}{l}\text { Month with } \\
\text { maxima }\end{array}$ & $\begin{array}{l}\text { Biovolume } \\
\left(\mu \mathrm{m}^{3} \text { cell }^{-1}\right)\end{array}$ & $\begin{array}{l}\text { Carbon } \\
\left(\text { pg cell }^{-1}\right)\end{array}$ \\
\hline \multicolumn{7}{|l|}{ Order Strombidiida } \\
\hline Cyrtostrombidium sp.1 $70 \mu \mathrm{m}$ & Jan-Dec & 7 & 480 & Apr & 9,845 & 1,871 \\
\hline Cyrtostrombidium sp.2 $160 \mu \mathrm{m}$ & Apr-Jan & 3 & 80 & Oct & 170,893 & 32,470 \\
\hline Laboea strobila & Jan-Nov & 57 & 2,240 & Mar & 91,865 & 17,454 \\
\hline Strombidium capitatum & Jan-Oct & 23 & 1,120 & Apr & 99,785 & 18,959 \\
\hline Strombidium cf. acutum & Jan-Dec & 8 & 3,020 & Apr & 43,563 & 8,277 \\
\hline Strombidium cf. conicum & Mar-Sep & 16 & 360 & May & 24,877 & 4,727 \\
\hline Strombidium cf. emergens & Jan-Nov & 41 & 2,727 & Jun & 35,923 & 6,825 \\
\hline Strombidium cf. epidemum & Jan-Dec & 77 & 24,840 & Apr & 6,465 & 1,228 \\
\hline Strombidium cf. lynii & Jan-Dec & 39 & 487 & Aug & 36,968 & 7,024 \\
\hline Strombidium siculum & May-Sep & 6 & 73 & Jul & 11,375 & 2,161 \\
\hline Strombidium cf. stylifer & Jan-Dec & 78 & 2,480 & May & 7,296 & 1,386 \\
\hline Strombidium cf. sulcatum & Jan-Oct & 59 & 8,213 & May & 8,862 & 1,684 \\
\hline Strombidium cf. tressum & Mar-Sep & 22 & 2,640 & Apr & 9,694 & 1,842 \\
\hline Strombidium sp.1 $20 \mu \mathrm{m}$ & Jan-Dec & 71 & 4,987 & Jun & 4,977 & 946 \\
\hline Strombidium sp.2 $25 \mu \mathrm{m}$ & Feb-Sep & 14 & 1,680 & Jul & 2,463 & 468 \\
\hline Strombidium sp.3 $30 \mu \mathrm{m}$ a & Jan-Dec & 12 & 540 & Apr & 5,893 & 1,120 \\
\hline Strombidium sp.4 $30 \mu \mathrm{m} \mathrm{b}$ & Sep-May & 3 & 200 & May/Oct & 4,157 & 790 \\
\hline Strombidium sp.5 $35 \mu \mathrm{m}$ & Jan-Dec & 28 & 580 & Aug & 8,244 & 1,566 \\
\hline Strombidium sp.6 $50 \mu \mathrm{m}$ & Jan-Sep & 11 & 367 & Jul & 9,390 & 1,784 \\
\hline Strombidium sp.7 $60 \mu \mathrm{m}$ & Jan-Dec & 22 & 1,200 & Jul & 19,294 & 3,666 \\
\hline Strombidium sp.8 $100 \mu \mathrm{m}$ & Jan-Dec & 11 & 267 & May & 105,853 & 20,112 \\
\hline Tontonia gracillima & Jan-Dec & 74 & 3,740 & Aug & 25,089 & 4,767 \\
\hline Tontonia sp. & Jan-Dec & 17 & 2,553 & Jul & 3,886 & 738 \\
\hline \multicolumn{7}{|l|}{ Order Choreotrichida } \\
\hline Leegaardiella cf. ovalis & Jan-Dec & 36 & 380 & Feb & 5,594 & 1,063 \\
\hline Leegaardiella cf. sol & Jan-Dec & 20 & 780 & Apr & 22,301 & 4,237 \\
\hline Lohmanniella oviformis & Nov-Aug & 42 & 2,753 & Jun & 4,725 & 898 \\
\hline Pelagostrobilidium cf. neptunii & Jan-Nov & 40 & 407 & Jul & 54,726 & 10,398 \\
\hline Rimostrombidium cf. sphaericum & Jul-??? & $<1$ & 40 & Jul & 74,475 & 14,150 \\
\hline Rimostrombidium cf. spiralis & Jan-Dec & 22 & 207 & Oct & 18,578 & 3,530 \\
\hline Rimostrombidium sp. & Jan-Nov & 12 & 1,120 & May & 100,779 & 19,148 \\
\hline Strobilidium sp.1 $15 \mu \mathrm{m}$ & Jan-Nov & 44 & 10,160 & Aug & 1,061 & 202 \\
\hline Strobilidium sp. $245 \mu \mathrm{m}$ & Apr-Aug & 13 & 970 & Jun & 38,186 & 7,255 \\
\hline Strombidinopsis sp.1 $90 \mu \mathrm{m}$ & Jul-Apr & 10 & 40 & Mar/Oct & 94,898 & 18,031 \\
\hline Strombidinopsis sp. $2120 \mu \mathrm{m}$ & Jul-Dec & 11 & 333 & Jul & 103,546 & 19,674 \\
\hline \multicolumn{7}{|l|}{ Order Cyclotrichiida } \\
\hline Askenasia regina & May-Oct & 9 & 380 & Oct & 172,422 & 32,760 \\
\hline Askenasia sp. & Apr-Sep & 1 & 60 & Jun & 269,492 & 51,203 \\
\hline Askenasia stellaris & May-Sep & 14 & 473 & May & 50,965 & 9,683 \\
\hline Mesodinium cf. pupula & May-Mar & 6 & 680 & Aug & 4,102 & 779 \\
\hline Mesodinium major & Jan-Dec & 90 & 52,640 & Jun & 21,637 & 4,111 \\
\hline Mesodinium pulex & Jan-Dec & 20 & 1,600 & Aug & 2,258 & 429 \\
\hline Mesodinium rubrum & Jan-Dec & 100 & 31,760 & Jun & 2,356 & 448 \\
\hline
\end{tabular}


Table 1 continued

\begin{tabular}{|c|c|c|c|c|c|c|}
\hline Ciliates & $\begin{array}{l}\text { Observed } \\
\text { seasonality }\end{array}$ & $\begin{array}{l}\text { Occurrence } \\
\text { frequency }(\%)^{\mathrm{a}}\end{array}$ & $\begin{array}{l}\text { Maximum } \\
\text { (cells L }^{-1} \text { ) }\end{array}$ & $\begin{array}{l}\text { Month with } \\
\text { maxima }\end{array}$ & $\begin{array}{l}\text { Biovolume } \\
\left(\mu \mathrm{m}^{3} \text { cell }^{-1}\right)\end{array}$ & $\begin{array}{l}\text { Carbon } \\
\left(\text { pg cell }^{-1}\right)\end{array}$ \\
\hline \multicolumn{7}{|l|}{ Order Tintinnida } \\
\hline \multicolumn{7}{|l|}{ Acanthostomella sp. ${ }^{\mathbf{b}}$} \\
\hline Eutintinnus sp. $130 \mu \mathrm{m}$ & May-Oct & 14 & 240 & Oct & 4,169 & 792 \\
\hline Eutintinnus sp.2 $60 \mu \mathrm{m}$ & Aug-Oct & 4 & 120 & Aug & 32,695 & 6,212 \\
\hline Favella ehrenbergii & Jul-Oct & 11 & 327 & Sep & 100,917 & 19,174 \\
\hline Salpingella sp. & Oct-Jan & 8 & 260 & Nov & 1,953 & 371 \\
\hline Stenosemella cf. pacifica & Sep-Jun & 27 & 6,440 & May & 10,722 & 2,037 \\
\hline Tintinnid sp.1 $30 \mu \mathrm{m}$ & Jan-Dec & 14 & 1,800 & Jun & 1,496 & 284 \\
\hline Tintinnid sp.2 $70 \mu \mathrm{m}$ & Sep-Dec & 1 & 40 & Sep & 58,219 & 11,062 \\
\hline Tintinnidium cf. balechi & Jan-Dec & 29 & 1,360 & Jan & 4,114 & 782 \\
\hline Tintinnopsis bütschlii & Aug-Sep & 4 & 707 & Sep & 27,253 & 5,178 \\
\hline Tintinnopsis cf. cylindrical & Jul-Oct & 5 & 47 & Aug & 23,842 & 4,530 \\
\hline Tintinnopsis cf. parvula & Mar-Jan & 33 & 940 & Jul & 4,279 & 813 \\
\hline Tintinnopsis cf. radix & Aug-Oct & 3 & 80 & Oct & 27,489 & 5,223 \\
\hline Tintinnopsis sp. & Jan-Jul & 10 & 40 & Jun & 34,653 & 6,584 \\
\hline \multicolumn{7}{|l|}{ Order Euplotida } \\
\hline Aspidisca sp. & Apr-Nov & 1 & 13 & Nov & 18,368 & 3,490 \\
\hline Diophrys cf. appendiculata & Feb-Oct & 3 & 13 & Jul & 13,225 & 2,513 \\
\hline Euplotes cf. trisulcatus & Apr-Dec & 18 & 353 & Jul & 7,561 & 1,437 \\
\hline \multicolumn{7}{|l|}{ Order Urostylida } \\
\hline Holosticha sp. & Jan-Dec & 20 & 627 & Sep & 3,388 & 644 \\
\hline Metaurostylopsis cf. salina & Nov-??? & 2 & 53 & Nov & 4,349 & 826 \\
\hline Thigmokeronopsis cf. stoecki & Aug-??? & 1 & 20 & Aug & 7,307 & 1,388 \\
\hline \multicolumn{7}{|l|}{ Order Sporadotrichida } \\
\hline Tachysoma cf. dragescoi & Mar-Dec & 10 & 93 & May & 3,739 & 710 \\
\hline \multicolumn{7}{|l|}{ Order Heterotrichida } \\
\hline Condylostentor sp. & Aug-Sep & 2 & 7 & Aug/Sep & 32,399 & 6,156 \\
\hline Condylostoma sp. & Mar-??? & $<1$ & 7 & Mar & 38,916 & 7,394 \\
\hline \multicolumn{7}{|l|}{ Order Pleurostomatida } \\
\hline Litonotus sp. & Aug-Nov & 3 & 13 & Sep & 3,582 & 681 \\
\hline Loxophyllum sp. & Jul-Nov & 2 & 27 & Nov & 893 & 170 \\
\hline \multicolumn{7}{|l|}{ Order Dysteriida } \\
\hline Dysteria sp. & Jan-Dec & 13 & 747 & Nov & 1,926 & 366 \\
\hline Hartmannula cf. derouxi & Apr-May & 2 & 10 & Apr & 12,537 & 2,382 \\
\hline \multicolumn{7}{|l|}{ Order Chlamydodontida } \\
\hline Chlamydonella cf. derouxi & Jan-Nov & 9 & 87 & Apr & 1,543 & 293 \\
\hline \multicolumn{7}{|l|}{ Order Endogenida } \\
\hline Acineta cf. compressa & Apr-Aug & 3 & 60 & Aug & 35,298 & 6,707 \\
\hline Acineta sp. & May-Jul & 2 & 13 & Jul & 27,560 & 5,236 \\
\hline \multicolumn{7}{|l|}{ Order Exogenida } \\
\hline Ephelota sp. & Apr-May & 2 & 7 & Apr/May & 50,772 & 9,647 \\
\hline \multicolumn{7}{|l|}{ Order Sessilida } \\
\hline Cothurnia sp. & Nov-??? & $<1$ & 7 & Nov & 1,779 & 338 \\
\hline Vorticella sp. & Jan-Dec & 3 & 620 & May & 6,729 & 1,278 \\
\hline \multicolumn{7}{|l|}{ Order Haptorida } \\
\hline Chaenea cf. vorax & May-??? & 2 & 7 & May & 38,040 & 7,228 \\
\hline Cyclotrichium sp. & Mar-Oct & 12 & 380 & Apr & 595,288 & 113,105 \\
\hline
\end{tabular}


Table 1 continued

\begin{tabular}{|c|c|c|c|c|c|c|}
\hline Ciliates & $\begin{array}{l}\text { Observed } \\
\text { seasonality }\end{array}$ & $\begin{array}{l}\text { Occurrence } \\
\text { frequency }(\%)^{\mathrm{a}}\end{array}$ & $\begin{array}{l}\text { Maximum } \\
\left(\text { cells L }^{-1}\right)\end{array}$ & $\begin{array}{l}\text { Month with } \\
\text { maxima }\end{array}$ & $\begin{array}{l}\text { Biovolume } \\
\left(\mu \mathrm{m}^{3} \text { cell }^{-1}\right)\end{array}$ & $\begin{array}{l}\text { Carbon } \\
\left(\text { pg cell }^{-1}\right)\end{array}$ \\
\hline Didinium gargantuan & Apr-Sep & 7 & 87 & Aug & 68,770 & 13,066 \\
\hline Lacrymaria sp. & Jan-Dec & 8 & 20 & Mar & 35,881 & 6,817 \\
\hline Spathidium sp. & Mar-Nov & 1 & 500 & Jun & 5,864 & 1,114 \\
\hline \multicolumn{7}{|l|}{ Order Prorodontida } \\
\hline Balanion comatum $15 \mu \mathrm{m}$ & Mar-Jan & 23 & 4,426 & Jun & 443 & 84 \\
\hline Balanion comatum $25 \mu \mathrm{m}$ & Jan-Nov & 32 & 1,880 & Jun & 2,356 & 448 \\
\hline Holophrya cf. caspica & May-Aug & 2 & 13 & May/Aug & 69,133 & 13,135 \\
\hline Holophrya cf. vorax & Aug-Oct & 8 & 80 & Aug & 92,074 & 17,494 \\
\hline Placus sp. & Apr-Nov & 27 & 273 & Aug & 8,954 & 1,701 \\
\hline Tiarina fusus & Jun-Dec & 22 & 1,687 & Sep & 7,561 & 1,437 \\
\hline \multicolumn{7}{|l|}{ Miscellaneous } \\
\hline Aloricate oligotrichs $<10 \mu \mathrm{m}$ & Jan-Dec & 29 & 3,080 & Jun & 347 & 66 \\
\hline Aloricate oligotrichs $<15 \mu \mathrm{m}$ & Jan-Dec & 55 & 19,360 & Jun & 805 & 153 \\
\hline Scuticociliates $10-30 \mu \mathrm{m}$ & Jan-Dec & 55 & 3,980 & Sep & 1,595 & 303 \\
\hline Scuticociliates $30-50 \mu \mathrm{m}$ & Jan-Dec & 41 & 1,320 & Aug & 17,641 & 3,352 \\
\hline
\end{tabular}

a Occurrence frequency $(\%)=$ the percentage of total occurrence times within 198 samples during the present monitoring

$\mathrm{b}$ There was no information on the abundance and seasonality for this species because only an empty lorica was recorded during the monitoring

Nano-sized aloricate oligotrichs $(5-15 \mu \mathrm{m})$, which were too small to identify even at an order level, predominated numerically mainly in summer with maxima of up to more than $1.9 \times 10^{4}$ cells $\mathrm{L}^{-1}$. Together with other tiny ciliates, such as Strombidium sp. $1(20 \mu \mathrm{m})$, Strobilidium sp. 1 $(15 \mu \mathrm{m})$, L. oviformis (Fig. 2j), Leegaardiella cf. ovalis and Balanion comatum (Fig. 2i), nano-sized ciliates probably play an essential role at Helgoland Roads by feeding on bacteria and picophytoplankton which are too small to be used by larger ciliates (Sorokin et al. 1996; Zingel et al. 2007).

Seven ciliate taxa were documented in the order Cyclotrichiida during the monitoring. In the previous monitoring, $M$. rubrum and $M$. major were recorded as two different size groups of $M$. rubra as also in many other studies (e.g. Montagnes and Lynn 1989; Rychert 2004). In the second monitoring, according to the recent study by Garcia-Cuetos et al. (2012), the smaller one $(15 \mu \mathrm{m})$ was assigned to the species $M$. rubrum and the larger one $(35 \mu \mathrm{m})$ was assigned to the species $M$. major. They have been recorded in all oceans of the world from polar regions to equatorial latitudes (Edwards and Burkill 1995; Sorokin et al. 1996; Pérez et al. 2000; Mironova et al. 2009; Wickham et al. 2011; Löder et al. 2012), and they are the most abundant and frequent ciliates at Helgoland Roads. M. rubrum (Fig. 2c) usually reached its maximum abundance in spring time $\left(3.18 \times 10^{4}\right.$ cells $\mathrm{L}^{-1}$ and $\left.14.2 \mu \mathrm{g} \mathrm{C} \mathrm{L}^{-1}\right)$, followed by a bloom of M. major (Fig. 2d) in June $\left(5.26 \times 10^{4}\right.$ cells L $^{-1}$ and $216.4 \mu \mathrm{g} \mathrm{C} \mathrm{L}^{-1}$ ). Montagnes and Lynn (1989) reported that the larger form occurred at colder times of the year and the smaller form occurred at warmer times. Garcia-Cuetos et al. (2012) mentioned that M. rubrum was abundant in the summer and early autumn and M. major was mainly found in the winter and early spring in Danish waters. However, such segregation cannot be confirmed by our results from Helgoland Roads. The "Medusa" form of M. major observed by Garcia-Cuetos et al. (2012) was found in autumn and winter time at Helgoland Roads during the second monitoring period. In addition, some reproductive individuals of both species observed further confirmed the separation of these two similar photosynthesis-performing ciliates.

Mesodinium pulex was one of the three ciliates recorded during the regular phytoplankton monitoring at Helgoland Roads. This organism has been reported from freshwater, brackish and marine waters (Song et al. 2009). Our monitoring results showed that it was less abundant (maximum value 100 cells $\mathrm{L}^{-1}$ ) in the second monitoring compared to the period 2007-2009 with maximum abundance $1.6 \times 10^{3}$ cells $\mathrm{L}^{-1}$.

The primarily planktonic genus Askenasia was another group recorded in the order Cyclotrichiida at Helgoland Roads. It has been documented in many marine ecosystems, such as the Atlantic Ocean, the Pacific Ocean, the North Sea and the English Channel (Earland and Montagnes 2002). Askenasia stellaris that was inaccurately identified as Mesodinium sp. in the first monitoring mainly occurred from May to September with a maximum 

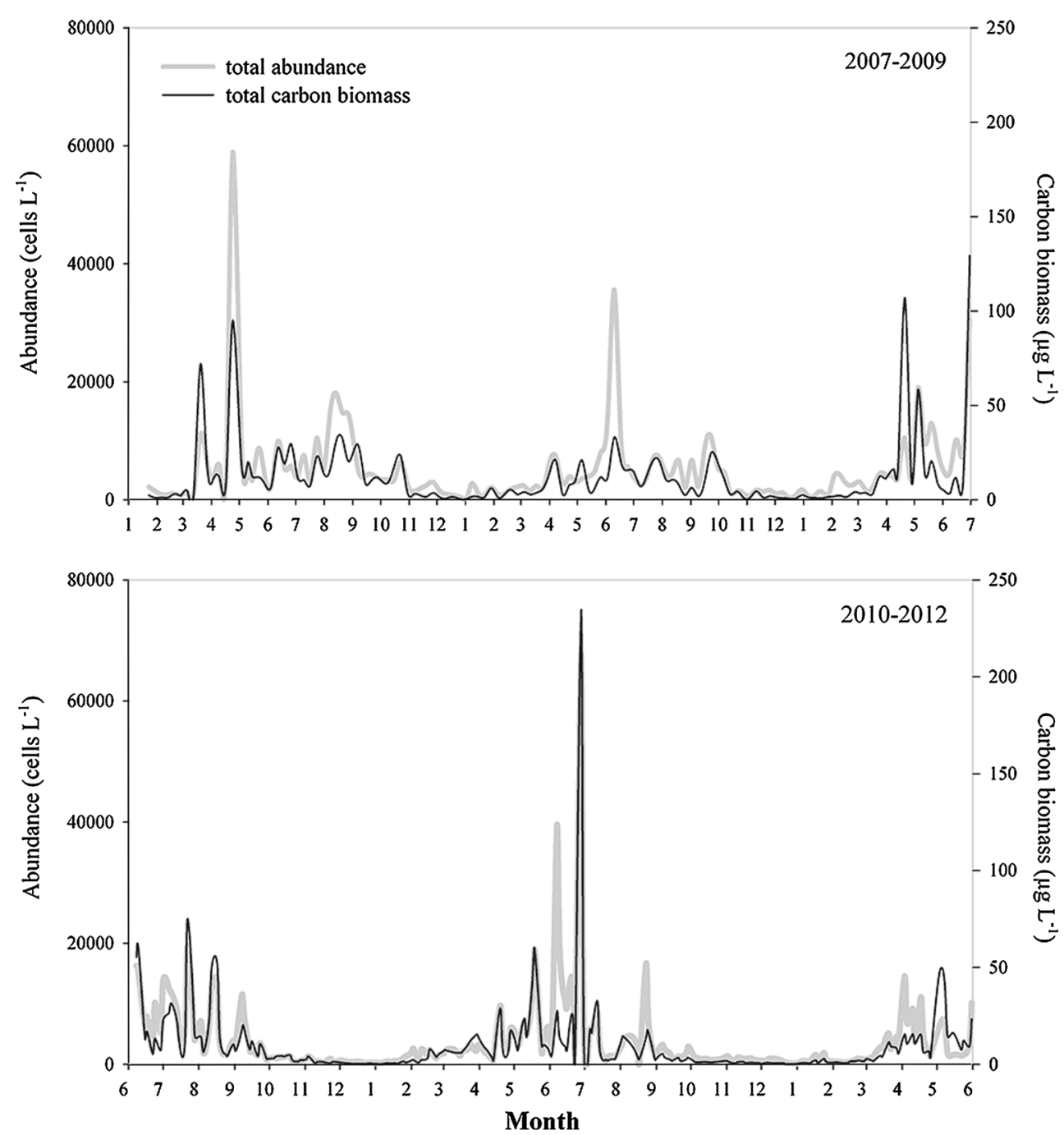

Fig. 1 The total abundance and carbon biomass of the ciliate community at Helgoland Roads during the first and second monitoring periods

abundance of about 470 cells $\mathrm{L}^{-1}$ at Helgoland. It was recorded in the plankton of coastal waters in some studies, such as the Finnish Gulf (Leegaard 1920), the North Sea near Hamburg (Kahl 1931), the Alligator Harbor, Florida (Borror 1963), and the Kandalaksha Gulf, White Sea (Burkovsky 1970).

Askenasia regina was previously found mainly in the upper water column with low abundances (Earland and Montagnes 2002). It occurred in the surface samples at the same time period as A. stellaris at Helgoland Roads. It can be easily differentiated from the latter due to its larger size. An unknown Askenasia sp. was recorded in the monitoring. It rarely occurred in spring and summer and was very conspicuous due to its large size $(50-100 \mu \mathrm{m}$ in diameter) and broad hemispherical body shape. It remains to be identified to species level.

Tintinnid ciliates are a ubiquitous component of the microzooplankton community in marine ecosystems
(Gavrilova and Dolan 2007). During the monitoring, 14 tintinnid taxa from 7 different genera were recorded. According to Pierce and Turner (1993), these tintinnids belong to two different distributional types: cosmopolitan tintinnids (Acanthostomella, Eutintinnus and Salpingella) and neritic tintinnids (Favella, Stenosemella, Tintinnopsis and Tintinnidium). As in many other coastal regions (e.g. Dolan and Marassé 1995; Sitran et al. 2009), tintinnids were generally a minor group in terms of abundance and carbon biomass at Helgoland Roads. They made up only about $3 \%$ of the total carbon biomass of the ciliate community. Tintinnidium cf. balechi (Fig. 2n), Stenosemella cf. pacifica (Fig. 2k) and Tintinnopsis cf. parvula were comparatively abundant among these tintinnids, and they were dominant species during late autumn and winter when the ciliate abundance was very low.

Tintinnidium cf. balechi has very long and thin collar membranelles $(20-35 \mu \mathrm{m})$, and its contractile stalk is 


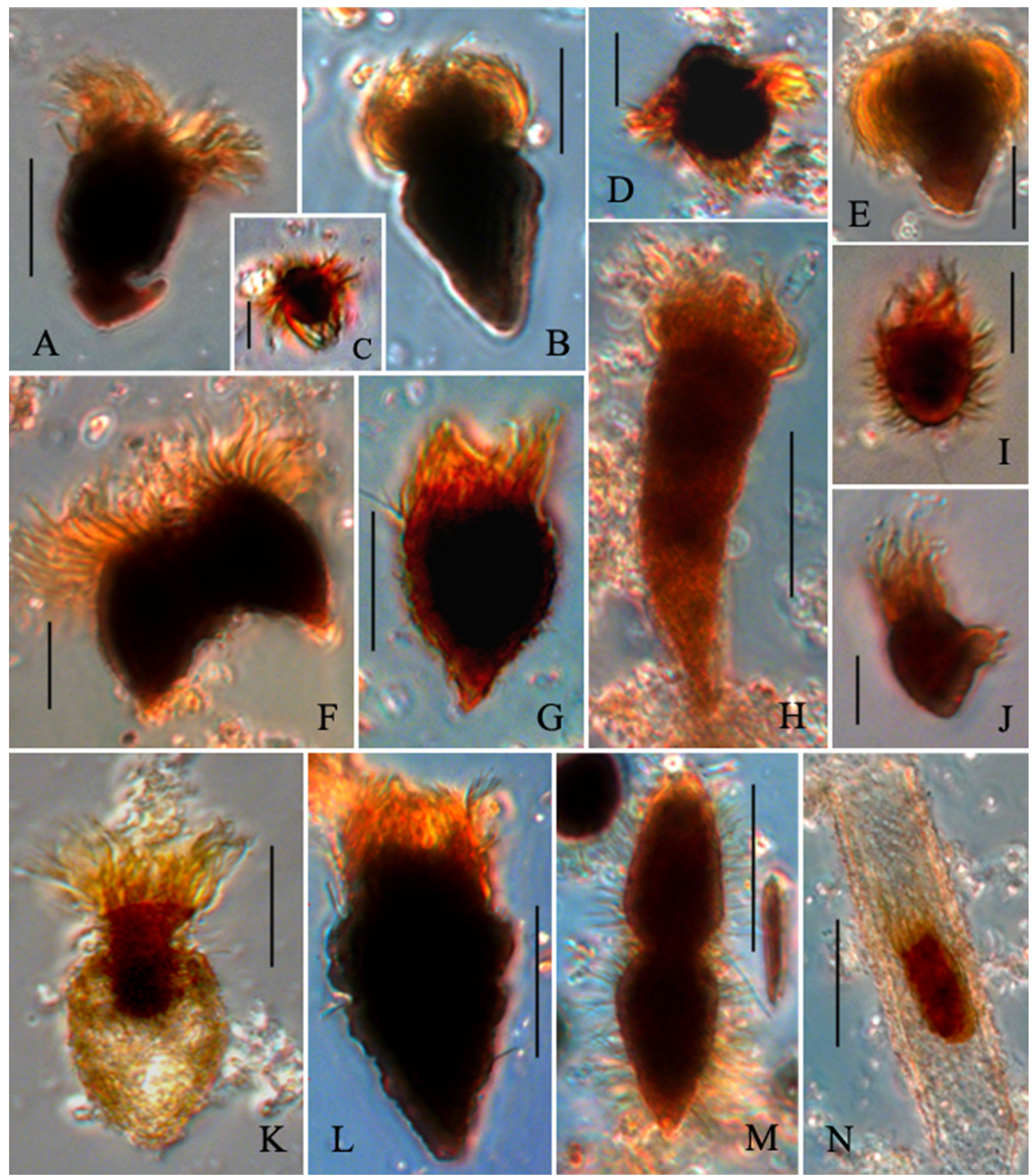

Fig. 2 Some dominant ciliates at Helgoland Roads (Lugol's fixed specimens). a Tontonia gracillima; b Strombidium cf. emergens; c Mesodinium rubrum; d Mesodinium major; e Pelagostrobilidium cf. neptunii; $\mathbf{f}$ Rimostrombidium sp.; $\mathbf{g}$ Strombidium cf. lynii;

attached to the wall of its lorica. In our samples, the lorica of this species covered a wide range from $50 \mu \mathrm{m}$ (broken lorica) to $150 \mu \mathrm{m}$ (complete lorica) due to its fragility. This h Strombidinopsis sp.; i Balanion comatum; j Lohmanniella oviformis; $\mathbf{k}$ Stenosemella cf. pacifica; $\mathbf{l}$ Laboea strobila; $\mathbf{m}$ Tiarina fusus; $\mathbf{n}$ Tintinnidium cf. balechi. Scale bars $=20 \mu \mathrm{m}(\mathbf{a}, \mathbf{b}, \mathbf{d}-\mathbf{g}, \mathbf{k}) ; 10 \mu \mathrm{m}$ $(\mathbf{c}, \mathbf{i}, \mathbf{j}) ; 30 \mu \mathrm{m}(\mathbf{h}, \mathbf{l}-\mathbf{n})$

organism usually appeared in autumn and remained until early summer with high abundances (maximum value

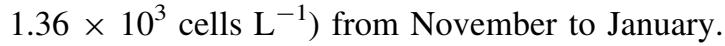


Stenosemella cf. pacifica is a widely distributed tintinnid, which has been recorded in the North Atlantic (Agatha and Tsai 2008), the Gulf of Mexico (Balech 1968), the Yellow Sea (Xu and Song 2005), the North Pacific (Kofoid and Campbell 1929, 1939) and the South Pacific (Burns 1983). According to our observations, its lorica was about 40-60 $\mu \mathrm{m}$ long and was composed of an agglomerated bowl and a short unobvious hyaline collar that sometimes was covered by an agglomerated second collar (as described in Agatha and Tsai 2008). It often occurred from late autumn until early spring at Helgoland Roads with an abundance normally varying between 20 and 150 cells $\mathrm{L}^{-1}$. In the spring of 2009 and the winter of 2011, its abundance reached much higher values than during other time periods and the maximum abundances were up to $6.44 \times 10^{3}$ and $1.04 \times 10^{3}$ cells $\mathrm{L}^{-1}$, respectively.

Tintinnopsis cf. parvula has a cosmopolitan distribution in marine and brackish coastal waters and occurs from the Arctic to trophic areas (Agatha 2010). Its lorica was about 40-65 $\mu \mathrm{m}$ long in our samples and composed of an agglomerated bowl and a narrow collar. It occurred infrequently throughout the year at Helgoland Roads with a maximum abundance of about 940 cells $\mathrm{L}^{-1}$. It can be difficult to distinguish Tintinnopsis cf. parvula from Stenosemella cf. pacifica because they sometimes coexisted, and their lorica have similar sizes and morphology. However, upon careful observation, Stenosemella cf. pacifica can be distinguished from Tintinnopsis cf. parvula due to its wider size (35-45 vs. 20-30 $\mu \mathrm{m})$ and the agglomerated second collar.

Tintinnopsis bütschlii (Fig. 3n) was first recorded at Helgoland Roads during the second monitoring. It is very easy to be distinguished from other tintinnids due to its obvious outward expansion of the lorica opening. It occurred only in August and September 2010 with a maximum abundance of 700 cells $\mathrm{L}^{-1}$, but it did not appear in any of the other samples. The large tintinnid Favella ehrenbergii, which has been recorded in many marine regions, such as the Black Sea (Gavrilova and Dolan 2007), the Baltic Sea (Mironova et al. 2009) and the Yellow Sea (Xu et al. 2011), normally occurred in July and disappeared in October at Helgoland Roads. It was usually present in low abundances ranging between 10 and 50 cells $\mathrm{L}^{-1}$, though sometimes its abundance reached more than 100 cells $\mathrm{L}^{-1}$, and its maximum abundance recorded was 330 cells $\mathrm{L}^{-1}$. Salpingella sp. was a small tintinnid that mainly occurred in autumn with an abundance varying between 10 and 260 cells $\mathrm{L}^{-1}$. Two different Eutintinnus species with cell lengths of about 30 and $60 \mu \mathrm{m}$ respectively were recorded. Both species showed very low abundances (less than 50 cells $\mathrm{L}^{-1}$ ). Tintinnopsis cf. radix and Tintinnopsis cf. cylindrica were identified as the same species in the first monitoring. Though they had a similar shape, the lorica of Tintinnopsis cf. cylindrica $(120-180 \mu \mathrm{m})$ was much smaller than that of Tintinnopsis cf. radix (250-300 $\mu \mathrm{m})$. In addition, we recorded an empty lorica of Acanthostomella sp. only once during the monitoring.

Typically periphytic and benthic ciliates

Besides the typically planktonic groups mentioned above, another 32 ciliate taxa from 11 different orders were recorded during the monitoring. Most of them were rare species and occurred at very low abundances and frequencies at Helgoland Roads, such as Diophrys cf. appendiculata (Fig. 3a) and Aspidisca sp. from the order Euplotida, Metaurostylopsis cf. salina (Fig. 3m) and Thigmokeronopsis cf. stoecki (Fig. 3i) from the order Urostylida, Condylostoma sp. and Condylostentor sp. from the order Heterotrichida, Litonotus sp. (Fig. 3d) and Loxophyllum sp. from the order Pleurostomatida, Hartmannula cf. derouxi (Fig. 3b) from the order Dysteriida, Chlamydonella cf. derouxi from the order Chlamydodontida, Acineta cf. compressa (Fig. 3g) and Acineta sp. from the order Endogenida, Ephelota sp. from the order Exogenida, Cothurnia sp. (Fig. 3c) from the order Sessilida, Cyclotrichium sp., Didinium gargantua (Fig. 3j), Spathidium sp., Lacrymaria sp. (Fig. 31) and Chaenea cf. vorax (Fig. 3h) from the order Haptorida, Holophrya cf. caspica (Fig. 3k) and $H$. cf. vorax from the order Prorodontida.

Meanwhile, some rare species occasionally occurred at high abundances and possibly played an important role during some periods of the year, such as Euplotes cf. trisulcatus which mainly occurred in spring and summer and was comparatively more abundant in 2010 with a maximum abundance about 350 cells $\mathrm{L}^{-1}$. Holosticha sp. was merely present in summer and also more abundant in 2010 than in other monitoring years with a maximum abundance of more than 600 cells L ${ }^{-1}$. Dysteria sp. (Fig. 3F) was first recorded in November 2010 at Helgoland Roads, and its maximum abundance was up to 750 cells $\mathrm{L}^{-1}$. Vorticella sp. which is a typical sessile ciliate was frequently recorded in the first monitoring with a maximum abundance of 620 cells $\mathrm{L}^{-1}$. In the second monitoring, it was only recorded five times altogether, within which it was abundant at two times in November 2011 with abundances of 200 and 287 cells $\mathrm{L}^{-1}$, respectively.

Balanion comatum (Fig. 2i), which is a nano-sized ciliate with cell lengths ranging from 10 to $25 \mu \mathrm{m}$, normally occurred from spring until the end of autumn with maxima often in May and June. Its maximum abundance was nearly $5.70 \times 10^{3}$ cells $\mathrm{L}^{-1}$ during the first monitoring period 


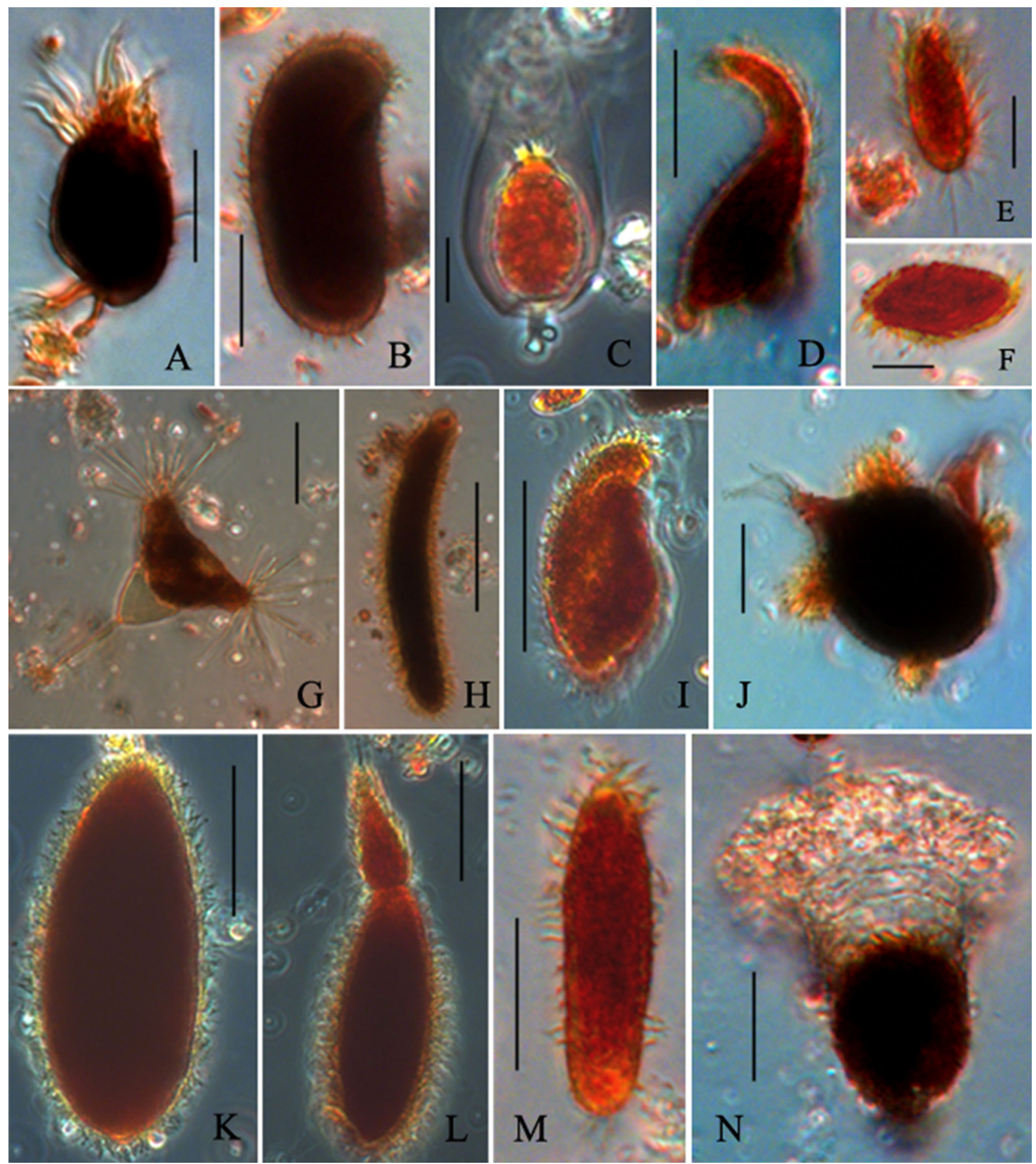

Fig. 3 Some rare ciliates at Helgoland Roads (Lugol's fixed specimens). a Diophrys cf. appendiculata; b Hartmannula cf. derouxi; C Cothurnia sp.; d Litonotus sp.; e Uronema cf. marinum; f Dysteria sp.; $\mathbf{g}$ Acineta $\mathrm{cf}$. compressa; $\mathbf{h}$ Chaenea $\mathrm{cf}$. vorax; i Thigmokeronopsis

and $2.30 \times 10^{3}$ cells $\mathrm{L}^{-1}$ during the second monitoring period. T. fusus (Fig. 2m) was one of the dominant ciliates at Helgoland Roads during late summer and autumn with cf. stoecki; j Didinium gargantua; $\mathbf{k}$ Holophrya cf. caspica; I Lacrymaria sp.; m Metaurostylopsis cf. salina; n Tintinnopsis bütschlii. Scale bars $=20 \mu \mathrm{m}(\mathbf{a}, \mathbf{b}, \mathbf{d}, \mathbf{j}, \mathbf{m}, \mathbf{n}) ; 10 \mu \mathrm{m}(\mathbf{c}, \mathbf{e}, \mathbf{f})$; $40 \mu \mathrm{m}(\mathbf{g}-\mathbf{i}, \mathbf{k}, \mathbf{l})$

maximum abundances of $1.52 \times 10^{3}$ cells $\mathrm{L}^{-1}$ in the first monitoring period and $1.69 \times 10^{3}$ cells $\mathrm{L}^{-1}$ in the second monitoring period. 
Scuticociliates at Helgoland Roads were simply divided into two different size groups during the monitoring due to the difficulties in identifying this complex ciliate group. Uronema cf. marinum (Fig. 3e) and Pleuronema cf. coronatum were two commonly recorded scuticociliate species. Uronema cf. marinum normally occurred at low numbers. However, its abundance was extremely high $\left(3.98 \times 10^{3}\right.$ cells $\left.\mathrm{L}^{-1}\right)$, and several conjugation individuals were observed at one time in September 2010. It is known that scuticociliates mainly feed on bacteria (Song et al. 2009), so that they may play a certain role in transferring energy from picoplankton to higher trophic levels together with other nano-sized ciliates.

Although these typically periphytic and benthic ciliates occurred at low abundances and frequencies in the water column, they probably play a minor but rather specific role in the ciliate community as they are known for their significant contribution to the stability of the community structure in disturbed or polluted natural systems (Caspers and Karbe 1967; Sládeček 1973; Xu et al. 2011).

\section{Comparison with other marine regions}

This study presents the first detailed checklist of the ciliate community at Helgoland Roads, the North Sea. This is important because to date, little is known about the potential role these organisms might play in this marine region (Wiltshire et al. 2010). Comparing these new results with other marine regions shows that in terms of diversity, the number ( 89 taxa) recorded in this study is similar to those of many other marine areas, such as the Yellow Sea (78 species in coastal waters of Incheon, Korea, Xu et al. 2011) and the Bellingshausen and Amundsen Seas, west of the Antarctic Peninsula (70 species, Wickham et al. 2011). In the Irminger Sea, Montagnes et al. (2010) recorded around 80 ciliate morphotypes with strombidiids (26 taxa) and tintinnids (16 taxa) being the highest in terms of taxa number, which is quite similar to that found in this study. However, Mironova et al. (2009) reported about 160 typically planktonic ciliates in a review paper on the planktonic ciliates of the Baltic Sea, which is probably due to the comprehensive long-term studies on the ciliate fauna overall in the Baltic Sea and also its diverse water bodies with different salinities and nutrient loads.

In terms of species composition, the ciliate community at Helgoland Roads was dominated by aloricate oligotrichs and choreotrichs, mainly Strombidium spp., Strobilidium spp., Tontonia spp. and L. strobila, which are typical of many coastal and oceanic waters including the Irish Sea (Edwards and Burkill 1995), the southern North Sea (Steif 1988), the Baltic Sea (Mironova et al. 2009), the Irminger Sea (Montagnes et al. 2010), the Bering Sea and North Pacific (Sorokin et al. 1996). As in many other coastal waters, $M$. rubrum and $M$. major are very important components of the ciliate community at Helgoland Roads. Similarly, on the northwest shelf of the Bering Sea, up to $30-40 \%$ of the ciliate community was comprised of $M$. rubrum (probably the mixture of $M$. rubrum and M. major, Sorokin et al. 1996). In the Bornholm Basin (the southern part of the central Baltic Sea), they dominated the microzooplankton communities in spring and early summer with a biomass 200-300 $\mathrm{g} \mathrm{C} \mathrm{L}^{-1}$ (Mironova et al. 2009). However, in Jiaozhou Bay, in the Yellow Sea, both $\mathrm{Me}$ sodinium species were not documented during a 1-year biweekly investigation on ciliate community at 5 stations (Jiang et al. 2011). In the Irminger Basin of the North Atlantic, Montagnes et al. (2008) recorded relatively low abundances $\left(0-5 \times 10^{3}\right.$ cells $\left.\mathrm{L}^{-1}\right)$ compared with that found in coastal areas. In the deep Bering Sea, they were rare, comprising only 3-6\% of the total ciliate abundance (Sorokin et al. 1996).

Although tintinnids were not as abundant as aloricate oligotrichs and Mesodinium spp. at Helgoland Roads, they were the group with the second highest diversity and 14 tintinnids were recorded in this study. Similarly, Graziano (1989) reported a total of 17 tintinnids in a study on the annual cycle of tintinnids off the Isle of Man. However, tintinnids exhibit a much higher diversity in some other marine areas compared to Helgoland Roads. In the Yellow Sea, Xu et al. (2011) reported 30 tintinnid taxa in the coastal waters of Incheon, and Jiang et al. (2011) reported 23 tintinnids accounting for $22 \%$ of the total abundance and $15 \%$ of the carbon biomass of the ciliate community in Jiaozhou Bay. A high species richness of tintinnids was often reported for the Mediterranean, such as 67 species in the Gulf of Milazzo (Sitran et al. 2009) and 57 species in a 4-year study in the Gulf of Naples (Modigh and Castaldo 2002). The dominance of tintinnids in the ciliate assemblage was also reported in some other locations, such as the Laizhou Bay, Bohai Sea (Zhang and Wang 2000) and the northern Hiroshima Bay, the Seto Inland Sea (Kamiyama 1994). Suzuki and Taniguchi (1998) speculated that tintinnids might be more adaptive to eutrophic environments than other ciliates, although the ecological processes were not clear.

The total abundance and carbon biomass of the ciliate community at Helgoland Roads ranged between 0.14-67.7 $\times 10^{3}$ cells $\mathrm{L}^{-1}$ and $0.2-234.6 \mu \mathrm{g} \mathrm{C} \mathrm{L}^{-1}$, respectively (Fig. 1), which are similar to the values from the Baltic Sea where ciliate abundance ranged between $0.17-88 \times 10^{3}$ cells $\mathrm{L}^{-1}$ in the southern Baltic Sea and the biomass ranged from 13 to $300 \mu \mathrm{g} \mathrm{C} \mathrm{L}^{-1}$ in the Bornholm Basin (Mironova et al. 2009). However, the ciliate community at Helgoland Roads exhibited a wider range compared to many other temperate marine waters (Bojanić et al. 2005; Montagnes et al. 2010; Jiang et al. 2011) in 
terms of both abundance and carbon biomass, although the mean values were quite similar. For example, the maximum abundance at Helgoland Roads $\left(67.7 \times 10^{3}\right.$ cells $\left.\mathrm{L}^{-1}\right)$ is higher than the value reported from the Irish Sea where $24 \times 10^{3}$ cells $\mathrm{L}^{-1}$ were found in early June (Edwards and Burkill 1995). In the Yellow Sea, a distinct peak with $29.54 \times 10^{3}$ cells $\mathrm{L}^{-1}$ was recorded in August (Jiang et al. 2011). Such differences might result from the spatial and temporal resolution of the sampling in these studies, or the hydrological features and some other environmental factors of these marine areas.

The ciliate blooms at Helgoland Roads normally occurred in spring and summer and mainly consisted of photosynthesis-performing ciliates $M$. rubrum and $M$. major as well as some aloricate oligotrich ciliates. Vertical distribution of $M$. rubrum has been investigated in some studies, which reported that this ciliate appears to be most abundant in the upper layers, especially under bloom conditions (Fenchel 1968; McManus and Fuhrman 1986). Aloricate oligotrich ciliates can respond rapidly to the enhanced food availability (Löder et al. 2012) and exhibit high growth rates when abundant prey populations are available (Montagnes 1996). Many aloricate oligotrich ciliates are mixotrophic (Stoecker et al. 1987), such as $S$. capitatum and L. strobila, and can conduct vertical migration to get optimal nutrient and light conditions or avoid predation by predators (McManus and Fuhrman 1986; Pérez et al. 2000; Lynn 2008). In addition, ciliates probably exist in small patches in the plankton (Montagnes 1996), which might be an explanation of the fact that the ciliate abundance could vary dramatically during the monitoring.

Comparing the species composition of the ciliate communities between different marine regions is difficult partly due to the different methods used in the studies. In our case for reasons outlined in the methods above, we used acid Lugol's solution. The fixation of ciliates in plankton samples with Lugol's solution is sometimes criticized because it may sometimes not provide enough species-specific features in several taxa (e.g. Strombidium spp. and Strobilidium spp.) resulting in difficulties in identification below genus level (Agatha 2011). However, each method has its flaws. The traditional fixative, formalin, which may allow the observation of chlorophyll fluorescence to estimate the trophic status of ciliates, can erode the more fragile ciliates and thus cause severe loss of cells (Stoecker et al. 1989, 1994). Another fixative Bouin's solution, which can yield similar cell counts with acid Lugol's solution and causes less cell shrinkage, is much more toxic than Lugol's solution. Other methods like protargol staining, however, are not feasible to carry out in a routine monitoring programme. In spite of such different methods, it is interesting that the species composition of the ciliate communities at
Helgoland Roads and many other marine regions are quite similar to each other. This is most likely due to the fact that the majority of ciliates are cosmopolitans.

One specific feature of the ciliate community at Helgoland Roads is the presence of a large number of typically periphytic and benthic ciliates in the community, which is probably related to the shallow water depth of the North Sea around Helgoland $(5-10 \mathrm{~m})$. These ciliates were normally very rare, and some even only occurred once all through the year. These taxa occurred in the water column due to some reasons, such as disturbance by storms or stratification (Hausmann et al. 2007). These rare ciliate taxa are hard to find in a low-frequency monitoring programme and thus were absent in the first monitoring programme with only one sample per week. Furthermore, some ciliate taxa have similar morphological features, and it is very difficult to distinguish them from each other, especially after having been fixed by acid Lugol's solution. Thus, they were probably misidentified as other taxa or grouped in one taxon as "Euplotes spp." in the first monitoring period. Some ciliates with obviously distinctive morphological features, such as Tintinnopsis bütschlii and Tontonia sp., are, however, potentially newcomers to the ciliate community at Helgoland Roads as they could not have been ignored if they were present in the water samples. Tintinnopsis bütschlii was often recorded in warm waters, such as the Yellow Sea (Xu and Song 2005), the South China Sea (Tan et al. 2010) and the Aegean Sea (Durmus et al. 2011). Its occurrence at Helgoland Roads may be associated with the warming trend in this region, or may result from ballast water, which need to be monitored in future. Unfortunately, we could not prove this hypothesis due to the lack of data on the ciliate community at Helgoland Roads before the two monitoring periods. This highlights the importance of conducting such monitoring programmes on a continuous and regular basis, especially at a long-term sampling station like Helgoland Roads.

Nevertheless, although there are some inevitable deficiencies as in all studies, we have added substantially to our knowledge of ciliates at Helgoland Roads and presented here a detailed checklist as well as the information on the abundance, carbon biomass and seasonality of dominant ciliate taxa of the ciliate community in the southern North Sea. This study has already laid the cornerstone and provided North Sea researchers with a longneeded basic reference for investigations on the biogeography of ciliates.

Perspectives on future ciliate monitoring

Eighty-nine ciliate taxa were recorded in total, and this number is in line with most marine regions studied in the literatures. However, we still believe that the diversity of 
the ciliate community at Helgoland Roads was underestimated as some ciliate taxa had to be put into different size groups or morphotypes due to the methodological limitations described above. An example is Scuticociliates, which were simply divided into two different size groups in the monitoring, are very likely to include more taxa based on our live observations. The complex genus Strombidium is also possibly more diverse than presented here. Doherty et al. (2007) investigated the ciliate diversity within the subclasses Choreotrichia and Oligotrichia in coastal northwest Atlantic waters using molecular and morphological methods and found that the estimates of diversity based on molecular method were much higher for oligotrich ciliates, especially in the genus Strombidium which was 2 to 3 times higher than the number of distinct morphospecies observed microscopically. In recent years, molecular methods have been applied to the study of protist diversity in many different ecosystems and have revealed a large protist diversity, suggesting a large fraction of eukaryotic microbial communities remain to be discovered (Moreira and López-García 2002; Šlapeta et al. 2005). In spite of some inherent limitations, molecular methods are being advanced and can reveal cryptic species and genetic diversity hidden beneath morphological homogeneity (McManus and Katz 2009). Therefore, detailed investigations into the ecology of ciliates in the North Sea should be underpinned by combining morphological observations with molecular methods to gain a more precise evaluation on the diversity of ciliates, especially in aloricate oligotrichs and nano-sized ciliates (Doherty et al. 2007). These are the most productive and numerous part of the ciliate community at Helgoland Roads. Unfortunately, they are studied to a lesser extent than larger ciliates which have been potentially over-represented due to obvious methodological advantages.

Acknowledgments This study was part of a $\mathrm{PhD}$ thesis within the Food Web Project at the Alfred Wegener Institute for Polar and Marine Research, and we are grateful for the funding and financial support from China Scholarship Council. Furthermore, we want to thank the crew of the research vessels Aade for providing samples, Silvia Peters and Kristine Carstens for their help in the laboratory, Prof. David Montagnes, Prof. Larink and Dr. Jiang for their help on species identification. Last but not least many thanks to the whole team of the AWI Food Web Project and the comments of anonymous reviewers.

\section{References}

Agatha S (2010) Redescription of Tintinnopsis parvula Jörgensen, 1912 (Ciliophora: Spirotrichea: Tintinnina), including a novel lorica matrix. Acta Protozool 49:213-234

Agatha S (2011) Global diversity of aloricate Oligotrichea (Protista, Ciliophora, Spirotricha) in marine and brackish sea water. PLoS ONE 6:1-13
Agatha S, Tsai SF (2008) Redescription of the tintinnid Stenosemella pacifica Kofoid and Campbell, 1929 (Ciliophora, Spirotricha) based on live observation, protargol impregnation, and scanning electron microscopy. J Eukaryot Microbiol 55:75-85

Azam F, Fenchel T, Field JG, Gray JS, Meyer-Reil LA, Thingstad F (1983) The ecological role of water-column microbes in the sea. Mar Ecol Prog Ser 10:257-263

Balech E (1968) Algunas especies nuevas o interesantes de tintinnidos del Golfo de Mexico y Caribe. Revista Mus Argent Cienc Nat Hidrobiol 2:165-197

Bojanić N, Šolić M, Krstulović N, Šestanović S, Marasović I, Ninčević Ž (2005) Temporal variability in abundance and biomass of ciliates and copepods in the eutrophicated part of Kaštela Bay (Middle Adriatic Sea). Helgol Mar Res 59:107-120

Borror AC (1963) Morphology and ecology of the benthic ciliated protozoa of Alligator Harbor, Florida. Arch Protistenkd 106:465-534

Burkovsky I (1970) Ciliates of the sand littoral and sublittoral of Kandalaksha Gulf (White Sea) and the analysis on the fauna of the benthic ciliates of other seas. Acta Protozool 8:183-201

Burns DA (1983) The distribution and morphology of tintinnids (ciliate protozoans) from the coastal waters around New Zealand. NZ J Mar Freshw Res 17:387-406

Carey PG (1992) Marine interstitial ciliates: an illustrated key. Chapman and Hall, London

Caspers H, Karbe L (1967) Vorschläge für eine saprobiologische Typisierung der Gewässer. Int Rev Gesamten Hydrobiol 52:145-162

Doherty M, Costas BA, McManus GB, Katz LA (2007) Cultureindependent assessment of planktonic ciliate diversity in coastal northwest Atlantic waters. Aquat Microb Ecol 48:141-154

Dolan JR (1997) Phosphorus and ammonia excretion by planktonic protists. Mar Geol 139:109-122

Dolan JR, Marassé C (1995) Planktonic ciliate distribution relative to a deep chlorophyll maximum: Catalan Sea, NW Mediterranean, June 1993. Deep Sea Res 42:1965-1987

Durmuş T, Balci M, Balkis N (2011) Species of genus Tintinnopsis Stein, 1867 in Turkish coastal waters and new record of Tintinnopsis corniger Hada, 1964. Pakistan J Zool 44(2):383-388

Earland KA, Montagnes DJS (2002) Description of a new marine species of Askenasia Blochmann, 1895 (Ciliophora, Haptoria), with notes on its ecology. J Eukaryot Microbiol 49:423-427

Edwards ES, Burkill PH (1995) Abundance, biomass and distribution of microzooplankton in the Irish Sea. J Plankton Res 17:771-782

Fenchel T (1968) On 'red water' in the Isefjord (Inner Danish waters) caused by the ciliate Mesodinium rubrum. Ophelia 5:245-253

Finlay BJ, Bannister P, Stewart J (1979) Temporal variation in benthic ciliates and the application of association analysis. Freshw Biol 9:45-53

Finlay BJ, Berninger UG, Clarke KJ, Cowling AJ, Hindle RM, Rogerson A (1988) On the abundance and distribution of protozoa and their food in a productive freshwater pond. Eur $\mathbf{J}$ Protistol 23:205-217

Franke HD, Buchholz F, Wiltshire KH (2004) Ecological long-term research at Helgoland (German Bight, North Sea): retrospect and prospect-an introduction. Helgol Mar Res 58:223-229

Garcia-Cuetos L, Moestrup Ø, Hansen PJ (2012) Studies on the genus Mesodinium II. ultrastructural and molecular investigations of five marine species help clarifying the taxonomy. J Eukaryot Microbiol 59(4):374-400

Garrison DL, Gibson A, Coale SL, Gowing MM, Okolodkov YB, Fritsen CH, Jeffries MO (2005) Sea-ice microbial communities in the Ross Sea: autumn and summer biota. Mar Ecol Prog Ser 300:39-52 
Gavrilova N, Dolan JR (2007) A note on species lists and ecosystem shifts: Black Sea tintinnids, ciliates of the microzooplankton. Acta Protozool 46:279-288

Gifford DJ (1991) The protozoan-metazoan trophic link in pelagic ecosystems. J Protozool 38:81-86

Graziano C (1989) On the ecology of tintinnids (Ciliophora: Oligotrichida) in the North Irish Sea. Estuar Coast Shelf Sci 29:233-245

Greve W, Reiners F, Nast J, Hoffmann S (2004) Helgoland Roads meso- and macrozooplankton time-series 1974 to 2004: lessons from 30 years of single spot, high frequency sampling at the only off-shore island of the North Sea. Helgol Mar Res 58:274-288

Hartwig E (1973) Die Ciliaten des Gezeiten-Sandstrandes der Nordseeinsel Sylt I. Systematik. In: Mikrofauna des Meeresbodens. Akademie der Wissenschaften und der Literatur, Mainz, pp 385-453

Hausmann K, Huelsmann N, Radek R (2007) Protistology. China Ocean University Press, Qingdao

Hillebrand H, Dürselen CD, Kirschtel D, Pollingher U, Zohary T (1999) Biovolume calculation for pelagic and benthic microalgae. J Phycol 35:403-424

Jiang Y, Xu HL, Al-Rasheid KAS, Warren A, Hu XZ, Song WB (2011) Planktonic ciliate communities in a semi-enclosed bay of Yellow Sea, northern China: annual cycle. J Mar Biol Assoc UK 91:97-105

Johansson M, Gorokhova E, Larsson U (2004) Annual variability in ciliate community structure, potential prey and predators in the open northern Baltic Sea proper. J Plankton Res 26:67-80

Kahl A (1931) Über die verwandtschaftlichen Beziehungen der Suctorien zu den prostomen Infusorien. Arch Protistenkd $73: 423-481$

Kamiyama T (1994) The impact of grazing by microzooplankton in northern Hiroshima Bay, the Seto Inland Sea, Japan. Mar Biol 119:77-88

Kofoid CA, Campbell AS (1929) A conspectus of the marine and freshwater Ciliata belonging to the suborder Tintinnoinea, with descriptions of new species principally from the Agassiz expedition to the eastern tropical Pacific 1904-1905. Univ Calif Publ Zool 34:1-403

Kofoid CA, Campbell AS (1939) The tintinnoinea of the eastern tropical Pacific. Bull Mus Comp Zool Harvard 84:1-473

Küsters E (1974) Ökologische und systematische Untersuchungen der Aufwuchsciliaten im Königshafen bei List/Sylt. Archiv für Hydrobiologie, Stuttgart

Laval-Peuto M, Salvano P, Gayol P, Greuet C (1986) Mixotrophy in marine planktonic ciliates: ultrastructural study of Tontonia appendiculariformis (Ciliophora, Oligotrichina). Mar Microb Food Webs 1:81-104

Leegaard C (1920) Mikroplankton from the finnish waters during the month of May 1912. Acta Soc Fauna Flora Fenn 48:1-41

Legendre L, Rassouldezgan F (1995) Plankton and nutrient dynamics in marine waters. Ophelia 41:153-172

Liu HB, Dagg MJ, Wu CJ, Chiang KP (2005) Mesozooplankton consumption of microplankton in the Mississippi River plume, with special emphasis on planktonic ciliates. Mar Ecol Prog Ser 286:133-144

Löder MGJ, Meunier C, Wiltshire KH, Boersma M, Aberle N (2011) The role of ciliates, heterotrophic dinoflagellates and copepods in structuring spring plankton communities at Helgoland Roads, North Sea. Mar Biol 158:1551-1580

Löder MGJ, Kraberg AC, Aberle N, Peters S, Wiltshire KH (2012) Dinoflagellates and ciliates at Helgoland Roads, North Sea. Helgol Mar Res 66:11-23

Lynn DH (2008) The ciliated protozoa. Characterization, classification and guide to the literature, 3rd ed. Springer, Berlin
Lynn DH, Montagnes DJS (1991) Global production of heterotrophic marine planktonic ciliates. In: Reid PC, Turley CM, Burkhill PH (eds) Protozoa and their role in marine processes, vol 25., NATO PublicationsSpringer, Berlin, pp 281-307

Maeda M, Carey PG (1985) An illustrated guide to the species of the family Strombidiidae (Oligotrichida, Ciliophora), free swimming protozoa common in the aquatic environment. Bull Ocean Res Inst Univ Tokyo 19:1-68

McManus GB, Fuhrman JA (1986) Photosynthetic pigments in the ciliate Laboea strobila from Long Island Sound, USA. J Plankton Res 8:317-327

McManus GB, Katz LA (2009) Molecular and morphological methods for identifying plankton: what makes a successful marriage? J Plankton Res 31:1119-1129

Mironova EI, Telesh IV, Skarlato SO (2009) Planktonic ciliates of the Baltic Sea (a review). Inland Water Biol 2:13-24

Modigh M, Castaldo S (2002) Variability and persistence in tintinnid assemblages at a Mediterranean coastal site. Aquat Microb Ecol 28:299-311

Montagnes DJS (1996) Growth responses of planktonic ciliates in the genera Strobilidium and Strombidium. Mar Ecol Prog Ser 130:241-254

Montagnes DJS (2003) Planktonic ciliate project internet homepage. http://www.liv.ac.uk/ciliate/intro.htm

Montagnes DJS, Lynn DH (1989) The annual cycle of Mesodinium rubrum in the waters surrounding the Isles of Shoals, Gulf of Maine. J Plankton Res 11:193-201

Montagnes DJS, Allen J, Brown L, Bulit C, Davidson R, Diaz-Avalos C, Fielding S, Heath M, Holliday NP, Rasmussen J, Sanders R, Waniek JJ, Wilson D (2008) Factors controlling the abundance and size distribution of the phototrophic ciliate Myrionecta rubra in open waters of the North Atlantic. J Eukaryot Microbiol 55:457-465

Montagnes DJS, Allen J, Brown L, Bulit C, Davidson R, Fielding S, Heath M, Holliday NP, Rasmussen J, Sanders R, Waniek JJ, Wilson D (2010) Role of ciliates and other microzooplankton in the Irminger Sea (NW Atlantic Ocean). Mar Ecol Prog Ser 411:101-115

Moreira D, López-García P (2002) The molecular ecology of microbial eukaryotes unveils a hidden world. Trends Microbiol 10:31-38

Park JS, Myung G, Kim HS, Cho BC, Yih W (2007) Growth responses of the marine photosynthetic ciliate Myrionecta rubra to different cryptomonad strains. Aquat Microbial Ecol 48:83-90

Pérez MT, Dolan JR, Vidussi F, Fukai E (2000) Diel vertical distribution of planktonic ciliates within the surface layer of the NW Mediterranean (May 1995). Deep Sea Res I 47:479-503

Pierce RW, Turner JT (1992) Ecology of planktonic ciliates in marine food webs. Rev Aquat Sci 6:139-181

Pierce RW, Turner JT (1993) Global biogeography of marine tintinnids. Mar Ecol Prog Ser 94:11-26

Pratt JR, Cairns J (1985) Functional groups in the Protozoa: roles in differing ecosystems. J Protozool 32:415-423

Putt M, Stoecker DK (1989) An experimentally determined carbon: volume ratio for marine "oligotrichous" ciliates from estuarine and coastal waters. Limnol Oceanogr 34:1097-1103

Rychert K (2004) The size structure of the Mesodinium rubrum population in the Gdańsk Basin. Oceanologia 46:439-444

Sherr EB, Sherr BF (1987) High rates of consumption of bacteria by pelagic ciliates. Nature 325:710-711

Sitran R, Bergamasco A, Decembrini F, Guglielmo L (2009) Microzooplankton (tintinnid ciliates) diversity: coastal community structure and driving mechanisms in the southern Tyrrhenian Sea (Western Mediterranean). J Plankton Res 31:153-170

Sládeček V (1973) System of water quality from biological point of view. Arch Hydrobiol Ergeb Limnol 7:1-218 
Šlapeta J, Moreira D, López-García P (2005) The extent of protist diversity: insights from molecular ecology of freshwater eukaryotes. Proc R Soc B 272:2073-2081

Song WB, Zhao YJ, Xu KD, Hu XZ, Gong J (2003) Pathogenic protozoa in mariculture. Science Press, Beijing

Song WB, Warren A, Hu XZ (2009) Free-living ciliates in the Bohai and Yellow Sea. Science Press, Beijing

Sorokin YI, Sorokin PY, Mamaeva TI (1996) Density and distribution of bacterioplankton and planktonic ciliates in the Bering Sea and North Pacific. J Plankton Res 18:1-16

Steif B (1988) Fluctuation and significance of microzooplankton at Helgoland. In: Biogeochemistry and distribution of suspended matter in the North Sea and implications to fisheries biology. Mitt Geol Palaeontol Inst Univ Hamburg 65:423-437

Stoecker DK, Michaels AE, Davis LH (1987) Large proportion of marine planktonic ciliates found to contain functional chloroplasts. Nature 326:790-792

Stoecker DK, Taniguichi A, Michaels AE (1989) Abundance of autotrophic, mixotrophic and heterotrophic planktonic ciliates in Shelf and slope waters. Mar Ecol Prog Ser 50:241-254

Stoecker DK, Gifford DJ, Putt M (1994) Preservation of marine planktonic ciliates: loss and cell shrinkage during fixation. Mar Ecol Prog Ser 110:293-299

Suzuki T, Taniguchi A (1998) Standing crops and vertical distribution of four groups of marine planktonic ciliates in relation to phytoplankton chlorophyll a. Mar Biol 132:375-382

Tan YH, Huang LM, Huang XP, Su Q, Shi X, Huang JR (2010) The relationships between ciliate composition, abundance, and environmental factors in Sanya Bay coral reef waters. Acta Ecolog Sin 30:6835-6844

Utermöhl H (1958) Zur Vervollkommnung der quantitative PlanktonMethodik. Mitt Int Ver Theor Angew Limnol 9:1-38

Vargas CA, Martínez RA, Cuevas LA, Pavez MA, Cartes C, Gonzalez HE, Escribano R, Daneri G (2007) The relative importance of microbial and classical food webs in a highly productive coastal upwelling area. Limnol Oceanogr 52:1495-1510

Vargas CA, Martínez RA, González HE, Silva N (2008) Contrasting trophic interactions of microbial and copepod communities in a fjord ecosystem, Chilean Patagonia. Aquat Microb Ecol 53:227-242

Wickham SA, Steinmair U, Kamennaya N (2011) Ciliate distributions and forcing factors in the Amundsen and Bellingshausen Seas (Antarctic). Aquat Microb Ecol 62:215-230

Wiltshire KH, Dürselen CD (2004) Revision and quality analyses of the Helgoland Reede long-term phytoplankton data archive. Helgol Mar Res 58:252-268

Wiltshire KH, Manly BFJ (2004) The warming trend at Helgoland Roads, North Sea: phytoplankton response. Helgol Mar Res 58:269-273

Wiltshire KH, Kraberg AC, Bartsch I, Boersma M, Franke HD, Freund J, Gebühr C, Gerdts G, Stockmann K, Wickels A (2010) Helgoland roads: 45 years of change. Estuar Coast 33:295-310

Xu DP, Song WB (2005) Tintinnid ciliates from Qingdao (Protozoa, Ciliophora, Tintinnida). Acta Zootaxonom Sin 30:501-508

Xu HL, Song WB, Warren A, Al-Rasheid KAS, Al-Farraj S, Gong J, $\mathrm{Hu}$ XZ (2008) Planktonic protist communities in a semi-enclosed mariculture pond: structural variation and correlation with environmental conditions. J Mar Biol Assoc UK 88:1353-1362

Xu KD, Choi JK, Lei YL, Yang EJ (2011) Marine ciliate community in relation to eutrophication of coastal waters in the Yellow Sea. Chin J Oceanol Limnol 29:118-127

Zhang WC, Wang R (2000) Summertime ciliate and copepod nauplii distributions and microzooplankton herbivorous activity in the Laizhou Bay, Bohai Sea, China. Estuar Coast Shelf Sci 51:103-114

Zingel P, Agasild H, Nõges T, Kisand V (2007) Ciliates are the dominant grazers on pico- and nanoplankton in a shallow, naturally highly eutrophic lake. Microbial Ecol 53:134-142 